\title{
Species specific uptake of radio-labelled phyto- detritus by benthic meiofauna from the Baltic Sea
}

\author{
Emil Ólafsson ${ }^{1, *}$, Helene Modig ${ }^{1}$, Wouter J. van de Bund ${ }^{2, * *}$ \\ ${ }^{1}$ Department of Zoology, and ${ }^{2}$ Department of Systems Ecology; Stockholm University, S-10691 Stockholm, Sweden
}

\begin{abstract}
The diatom Skeletonema costatum is one of the dominant phytoplankton species during spring in the northern Baltic Sea. We followed the uptake of radio-labelled $S$. costatum by all major meiofauna species in a laboratory experiment. The uptake of labelled diatom carbon varied greatly among major meiobenthic taxa and among species belonging to the same class or phylum. Both total uptake and uptake per unit biomass were by far highest in the ostracod Candona neglecta accounting for $46 \%$ of the total meiofauna uptake. The total uptake of ${ }^{14} \mathrm{C}$ was significantly different among all 3 common ostracod species, Candona neglecta taking 10 and 100 times more than Paracyprideis fennica and Heterocyprideis sorbyana respectively. Nematodes accounted for over $40 \%$ of the total uptake of ${ }^{14} \mathrm{C}$ in the microcosms, of which $84 \%$ was taken up by large nematode species such as Paracanthonchus spp. Nematodes with similar buccal cavities and of similar size showed surprisingly large differences in the uptake of the radio-labelled material. There seems to be quite strong selection both for and against the diatom among epistrate feeders as well as among so-called non-selective deposit feeders. Only a small portion of the total meiofauna population was found below $1 \mathrm{~cm}$ in the sediment; this was composed almost solely of nematodes. These nematodes assimilated as much ${ }^{14} \mathrm{C}$ per unit biomass as the surface ones did, which contradicts the hypothesis claiming that meiobenthic animals react in 2 ways to phytoplankton sedimentation, with surface feeders directly assimilating sedimented phytoplankton, while subsurface feeders experience a more stable food supply and rely only indirectly on sedimented phytoplankton.
\end{abstract}

KEY WORDS: Pelagic-benthic coupling $\cdot$ Food-web $\cdot$ Meiofauna $\cdot{ }^{14} \mathrm{C}$ radio label

\section{INTRODUCTION}

Sedimentation of organic material from phytoplankton blooms often represents a considerable amount of annual benthic organic inputs (see Graf 1992 for a review). Only a few studies have addressed the importance of plankton blooms for meiobenthos. The results are contradictory, with several studies indicating no or only a slight response of meiofauna taxa to sedimented plankton material (e.g. Fleeger et al. 1989, Fleeger \& Shirley 1990, Gooday et al. 1996, Webb 1996), while others indicate a tight link between spring bloom sedimentation and increase in the abundance or biomass of the meiofauna (e.g Goedkoop \& Johnson 1996, Olafsson \& Elmgren 1997). Radziejewska et al. (1996) found

\footnotetext{
-E-mail: emil.olafsson@zoologi.su.se

-Present address: Netherlands Institute of Ecology, Centre for Limnology, Box 299, 3600 BG Maarssen, The Netherlands
}

that major meiofauna taxa significantly correlated with sediment pigments in an area of low primary production, while under conditions of abundant pelagic production no such relationship was evident.

Meiofauna are known to utilise food resources that are produced in the pelagic zone, either directly by feeding on sedimented algal cells, or indirectly by feeding on decomposing organic matter with associated bacteria (for reviews see: Hicks \& Coull 1983, Heip et al. 1985, 1995). The diverse morphology of the mouth-parts of meiobenthic species has prompted researchers to classify these animals into various trophic groups. Wieser (1953), for instance, divided nematodes into 4 feeding categories depending on the armature of the buccal cavity, i.e. species with unarmed buccal cavities were considered as deposit feeders, either selective (small cavities) or non-selective (large cavities), and species with armed buccal cavities were considered as epistrate feeders or omni- 
vores/predators. Several authors have criticised this classification and made modifications by adding to and/or altering these 4 groups (Alongi \& Tietjen 1980 Romeyn \& Bouwman 1983, Schiemer 1984, Jensen 1987, Moens \& Vincx 1997).

It appears that many meiofauna species feed selectively, which may give rise to interspecific food preferences (e.g. Van den Berghe \& Bergmans 1981, Moens et al. 1996, Pace \& Carman 1996). Diatoms are usually the major component of the phytoplankton spring blooms reaching the bottom. Radioactive tracer techniques have been used in many experiments dealing with diatom grazing rates of meiobenthos. Label has either been added directly into experimental units (i.e. sediment or water-column; Daro 1978, Montagna 1984 Rudnick 1989, Widbom \& Frithsen 1995) or by prelabelling diatom cultures and then adding to experimental units (Decho 1986, Decho \& Fleeger 1988, Pace \& Carman 1996). Prelabelled material is particularly useful in testing food selectivity, but might give inaccurate estimates of overall grazing rates in the field (Moens \& Vincx 1996). However, there are also several problems associated with the use of direct addition of radioactive label $\left(\mathrm{NaH}^{1.4} \mathrm{CO}_{3}\right)$ for estimating selectivity and grazing rates of meiofauna, including absorption into surface tissues of grazers, ingestion of free label, homogenous label distribution, etc. (e.g. Montagna 1983, 1984, Carman et al. 1989, Carman 1990). Nonetheless the above-mentioned studies indicate species-specific uptake of diatoms among harpacticoid copepods (Decho 1986, Decho \& Fleeger 1988, Pace \& Carman 1996) and taxon-specific uptake by several major meiofaunal taxa (Montagna 1984, Rudnick 1989, Widbom \& Frithsen 1995). Further, Austen \& Warwick (1995) noted a decrease in diatom-feeding nematodes when diatoms were not offered as food for $16 \mathrm{wk}$, and Montagna et al. (1995) noted different responses among the major meiofauna taxa when diatoms were added to sediments.

During spring, in the cold waters of the northern Baltic Sea, the development of phytoplankton assemblages does not appear to be controlled by grazers, but rather by nutrient concentrations (Lignell et al. 1993). This results in a major build up of phytoplankton biomass, until availability of nitrogen and phosphorus becomes low, after which a large part of the bloom settles out (Kuparinen et al. 1984, Smetacek et al. 1984, Lignell et al. 1993). Although experimental evidence is lacking, the settling spring bloom material is probably a driving force for the benthic communities in the northern Baltic Sea, as it contributes the bulk of primary settling organic matter (i.e. not resuspended old material) on a yearly basis (Blomqvist \& Larsson 1994).

In a field study at a $37 \mathrm{~m}$ deep station in the northwestern Baltic proper, Olafsson \& Elmgren (1997) found that both meiofauna biomass and abundance increased rapidly following the spring bloom, although this was both taxon and species specific. For example, almost twice as many nematodes, the most abundant metazoans, were found after, compared to before, the spring bloom. The common epistrate feeders Paracanthonchus spp. increased about 4 -fold after the spring bloom, while the most abundant species, Calomicrolaimus honestus and Leptolaimus elegans, showed no significant seasonal variations. Furthermore, the highest numbers of the common deep-dwelling nematode, Sabatieria pulchra were found in autumn. The authors concluded that their results supported Rudnick's (1989) hypothesis that meiobenthic animals react in 2 ways to phytoplankton sedimentation, with surface feeders directly assimilating sedimented phytoplankton, while subsurface feeders experience a more stable food supply and rely only indirectly on sedimented phytoplankton.

Here we report on the first laboratory study in which the uptake of ${ }^{14} \mathrm{C}$ labelled diatoms by all major meiofauna species in a given area has been followed in intact cores. We chose to work with the diatom Skeletonema costatum as it is a dominant phytoplankton species in large areas of the Baltic Sea (e.g. Kononen et al. 1992), forms the major part of the settling spring bloom biomass (Heiskanen \& Kononen 1994), and is easily cultured and labelled in the laboratory

In this paper we specifically address the following questions: (1) Is there an interspecific difference in the assimilation of Skeletonema costatum among the major meiofaunal species? We expected that species within a given taxon (Ostracoda, Harpacticoida, etc.) would take up dissimilar amounts of this diatom. (2) Is there an inter-or intraspecific difference in the assimilation of $S$. costatum between the surface and the deeper living fauna? We expected relatively higher uptake by the surface living individuals. (3) Is there a difference in the uptake of $S$. costatum among the various nematode trophic groups? We expected that diatom feeders (Paracanthonchus spp. and Chromadorita fennica) would assimilate more than deposit feeders (Sabatieria pulchra) or predators (Sphaerolaimus $\mathrm{sp}$.).

\section{MATERIAL AND METHODS}

Prior to the onset of the spring bloom, 6 Kajak cores $\left(50 \mathrm{~cm}^{2}\right.$ ) were collected (21 March 1996) near the Asko Laboratory, in the northwestern Baltic proper $\left(58^{\circ} 49^{\prime} \mathrm{N}\right.$, $17^{\circ} 38^{\prime} \mathrm{E}$ ). The cores were retrieved from a $37 \mathrm{~m}$ deep muddy location, the same as in Olafsson \& Elmgren $(1997)$, and stored in a thermoconstant room $\left(4^{\circ} \mathrm{C}\right)$ in the dark. During storage individual cores were aerated 
using an airstone. The cores were left for approximately $3 \mathrm{wk}$ for the meiofauna to acclimatise; $2 \mathrm{wk}$ before adding the diatoms the microcosms were completely filled with water, with no air phase, and connected to a $1500 \mathrm{ml}$ water reservoir (Fig. 1). The water from the reservoirs was recirculated into the cores using peristaltic pumps; the residence time in the microcosms was $7.8 \mathrm{~h}$. A preliminary experiment showed that the water in the cores was homogeneously mixed at this pumping rate. The water reservoirs were aerated; the outgoing air was washed in tubes filled with $25 \mathrm{ml}$ Carbo-Sorb $\mathrm{E}$ (Packard) to retain outgoing $\mathrm{CO}_{2}$.

The diatom Skeletonema costatum was cultured at $15^{\circ} \mathrm{C}$ in artificial seawater (Kester et al. 1967) at a salinity of $15 \%$, with added nutrients (f/2 plus Si; Guillard 1975 ) and $25 \%$ reduced $\mathrm{NaHCO}_{3}$. Cultures were shaken manually once every $2 \mathrm{~d}$. Algae were labelled by adding $0.34 \mathrm{mCi} \mathrm{NaH}^{14} \mathrm{CO}_{3}$ (Amersham; specific activity $54.0 \mathrm{mCi} \mathrm{mmol}^{-1}$ ) to each culture flask $4 \mathrm{~d}$ after starting the culture. After an additional $7 \mathrm{~d}$ of incubation, the labelled algae were harvested by allowing them to settle for $5 \mathrm{~h}$ at $4^{\circ} \mathrm{C}$ in the dark in a separatory funnel. The labelled algae were washed by re-suspending them in clean medium and allowing them to settle again; this procedure was repeated twice. The final radioactivity in the diatoms was $0.38 \mathrm{mCi} g$ dry $\mathrm{wt}^{-1}$; this was measured by solubilizing dried algae overnight at $50^{\circ} \mathrm{C}$ in $80 \%$ Soluene-350 tissue solubilizer (Packard), adding $5 \mathrm{ml}$ scintillation cocktail (Hionic-Fluor, Packard) and counting on a liquid scintillation counter (see below).

Two months after sampling cores (22 May), $3 \mathrm{ml}$ diatom suspension containing $46.8 \mathrm{mg}$ dry wt and a total activity of $2.8 \times 10^{7} \mathrm{DPM}$ (disintegrations per minute) was added with a Pasteur pipette to each core, evenly distributing the algae over the whole sediment surface. Immediately after addition of the diatoms the $\mathrm{CO}_{2}$ traps were connected. Radioactivity in the $\mathrm{CO}_{2}$ traps was measured after $7 \mathrm{~d}, 9 \mathrm{~d}$ and 1 mo by taking a $1 \mathrm{ml}$ sub-sample from the traps, adding $10 \mathrm{ml}$ scintillation liquid (PermaFluor E+, Packard), and counting in a liquid scintillation counter (see below). The $\mathrm{CO}_{2}$ traps were then filled with fresh CarboSorb. At the same time, two $1 \mathrm{ml}$ water samples were taken from each water reservoir. To one of these samples $1 \mathrm{ml}$ CarboSorb was added to fix $\mathrm{CO}_{2}$, to the other $1 \mathrm{ml}$ of $1 \mathrm{~N} \mathrm{I} \mathrm{ICl}$ to release $\mathrm{CO}_{2}$. Water samples were counted in $10 \mathrm{ml}$ Hionic-Fluor (Packard). Dissolved ${ }^{14} \mathrm{CO}_{2}$ in the water was calculated from the activity in samples with fixed and released $\mathrm{CO}_{2}$; total released ${ }^{14} \mathrm{CO}_{2}$ was calculated from activity in the traps and dissolved ${ }^{14} \mathrm{CO}_{2}$.

On 18 June the experiment was terminated, 1 mo after the addition of algae. Each core was sectioned into 2 layers, 0 to $1 \mathrm{~cm}$ and 1 to $4 \mathrm{~cm}$, and small sub-

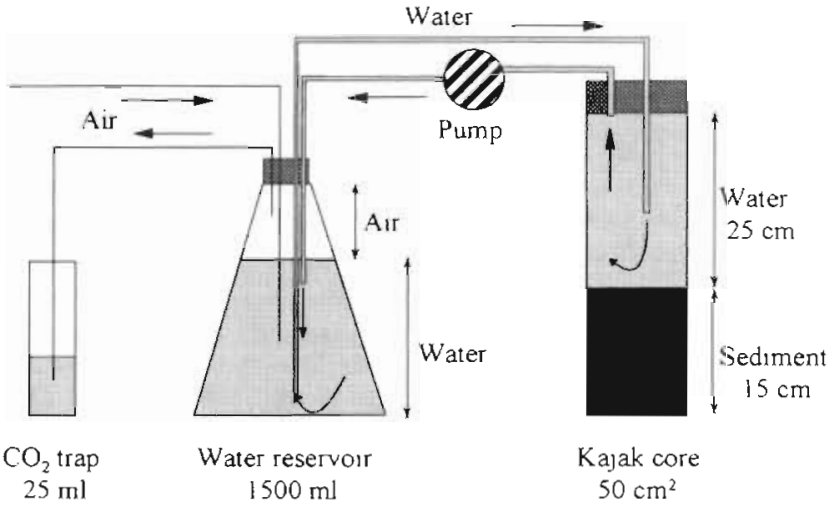

Fig. 1. Schematic illustration of the experimental set-up

samples (ca $3 \mathrm{~g}$ wet wt) were taken from both layers for radioactivity measurements in the sediment (see below). The rest of the sediment was then passed through 500 and $40 \mu \mathrm{m}$ sieves, and the $40 \mu \mathrm{m}$ screenings fixed in $4 \%$ formaldehyde solution for meiofaunal analysis. The meiofauna was extracted from the sediment using Ludox colloidal silica at a specific gravity of 1.15 (Ólafsson \& Elmgren 1997). As extraction efficiency for ostracods is often low (Ólafsson \& Elmgren 1997), the sediment was re-sieved ( $200 \mu \mathrm{m}$ mesh), and all ostracods picked out. Animals retained on $40 \mu \mathrm{m}$ sieves were enumerated, washed twice in distilled water by transferring them between watch-glasses and then placed in scintillation vials. Species or taxa were analysed separately for each Kajak core when the amount of radioactivity per group (at least $3 \mu \mathrm{g} \mathrm{C}$ ) was sufficient; those taxa found at low biomasses were pooled until they reached at least $3 \mu \mathrm{g} \mathrm{C}$. To facilitate collection of the larger nematode species, the meiofauna extracts were passed through 200 and $40 \mu \mathrm{m}$ sieves. Prior to gathering the larger nematodes, species were enumerated under a $50 \times$ stereo microscope and in some cases under higher magnification. Biomass was estimated from a size-weight relationship (see Ólafsson \& Elmgren 1997). Each nematode was classified as: adult male, adult female, gravid female or juvenile; the biomass was then estimated separately for each of these categories.

Sediment radioactivity was measured by solubilizing a small freeze-dried sample overnight at $50^{\circ} \mathrm{C}$ in $80 \%$ Soluene-350 (Packard), adding $10 \mathrm{ml}$ Hionic-Fluor (Packard) and counting using a liquid scintillation counter (see below). Meiofauna samples were dried at $60^{\circ} \mathrm{C}$ overnight, and solubilized overnight at $50^{\circ} \mathrm{C}$ in $80 \%$ Soluene-350 (Packard); $5 \mathrm{ml}$ Hionic-Fluor (Packard) was added to each sample. All radioactivity samples were counted with a LKB scintillation counter using a standard ${ }^{14} \mathrm{C}$ counting program. Quenching was corrected for each sample by measuring a quench- 
ing parameter (SQP[E]) using an external standard, and calculating counting efficiency from a calibration curve obtained from quenched standard samples.

Abiotic uptake of label by ostracods was assessed in 2 formaldehyde-treated microcosms (750 ml Erlenmeyer flasks of $78.5 \mathrm{~cm}^{2}$ bottom area, $1 \mathrm{~cm}$ deep sediment layer, connected to $1500 \mathrm{ml}$ water reservoir, water recirculated) where meiofauna was killed prior to adding labelled algae. This uptake was compared with uptake in 6 microcosms without formalin. Both treatments ran for 1 mo.

Differences in assimilation among the various species/taxa were investigated by means of 1 -way analyses of variance (ANOVA). Paired a posteriori comparisons were carried out with the Tukey test using $95 \%$ confidence limits. Prior to the ANOVA, all data were $\log _{10}(x+1)$ transformed and Cochran's C-test used to check the assumption of homoscedasticity.

Table 1. Average number per core, percentage, average individual size, percentage of total biomass, average, maximum and minimum specific organic carbon activity (DPM mgC ${ }^{-1}$ ) and total ${ }^{14} \mathrm{C}$ uptake per core for the major meiofaunal groups and species. "Not estimated

\begin{tabular}{|c|c|c|c|c|c|c|c|c|c|c|c|}
\hline \multirow[t]{2}{*}{ Taxon/species } & \multirow{2}{*}{$\begin{array}{l}\text { Depth } \\
(\mathrm{cm})\end{array}$} & \multicolumn{2}{|c|}{ Abundance } & \multirow{2}{*}{$\begin{array}{l}\text { Ind. } \\
\text { size } \\
(\mu \mathrm{gC})\end{array}$} & \multirow{2}{*}{$\begin{array}{c}\text { Total } \\
\text { biomass } \\
(\%)\end{array}$} & \multicolumn{4}{|c|}{$\mathrm{DPM} \mu \mathrm{gC}^{-1}$} & \multicolumn{2}{|c|}{$\begin{array}{c}\text { Total uptake } \\
\text { core } e^{-1}\end{array}$} \\
\hline & & Avg. & $\%$ & & & Avg & $\operatorname{Max}$ & Min & $\mathrm{n}$ & DPM & $\%$ \\
\hline \multicolumn{12}{|l|}{ Nematoda } \\
\hline Sabatieria pulchra & $0-1$ & 421 & 7 & 0.32 & 21 & 5 & 17 & 2 & 6 & 674 & 8 \\
\hline Paracanthonchus spp. & $0-1$ & 329 & 5 & 0.16 & 8 & 22 & 40 & 7 & 6 & 1165 & 14 \\
\hline Axonolaimus spinosus & $0-1$ & 121 & 2 & 0.09 & 2 & 22 & 34 & 7 & 5 & 237 & 3 \\
\hline Eleutherolaimus stenosoma & $0-1$ & 104 & 2 & 0.04 & 1 & 0 & - & - & 1 & 0 & 0 \\
\hline Sphaerolaimus sp. & $0-1$ & 116 & 2 & 0.40 & 8 & 2 & 3 & 0.3 & 2 & 80 & 1 \\
\hline Chromadorita fennica & $0-1$ & 87 & 1 & 0.08 & 1 & 0 & - & - & 1 & 0 & 0 \\
\hline Desmolaimus zeelandicus & $0-1$ & 42 & 1 & 0.15 & 1 & 2 & - & - & 1 & 13 & 0.2 \\
\hline \multicolumn{12}{|l|}{ Other nematodes $(<200 \mu \mathrm{m})$} \\
\hline Leptolaimus papilliger & $0-1$ & 1005 & 17 & 0.01 & & & & & & & \\
\hline Microlaimus globiceps & $0-1$ & 764 & 1.3 & 0.01 & & & & & & & \\
\hline Calomicrolaimus honestus & $0-1$ & 721 & 12 & 0.01 & & & & & & & \\
\hline Dichromadora sp. & $0-1$ & 612 & 10 & 0.05 & & & & & & & \\
\hline Leptolaimus elegans & $0-1$ & 480 & 8 & $0.01\}$ & 13 & 7 & 9 & 4 & 6 & 562 & 7 \\
\hline Halalaimus sp. & $0-1$ & 87 & 1 & 0.03 & & & & & & & \\
\hline Daptonema sp. & $0-1$ & 44 & 1 & 0.01 & & & & & & & \\
\hline Monhystera sp. & $0-1$ & 44 & 1 & 0.01 & & & & & & & \\
\hline Campylaimus gerlachi & $0-1$ & 22 & 0.4 & 0.01 & & & & & & & \\
\hline Sabatieria pulchra & $1-4$ & 371 & 6 & 0.33 & 20 & 4 & 9 & 1 & 6 & 460 & 5 \\
\hline Paracanthonchus spp. & $1-4$ & 14 & 0.2 & 0.16 & 0 & 27 & - & - & 1 & 62 & 1 \\
\hline Sphaerolaimus sp. & $1-4$ & 10 & 0.2 & 0.28 & 0 & 1 & - & - & 1 & 3 & 0.03 \\
\hline Chromadorita fennica & $1-4$ & 7 & 0.1 & 0.17 & 0 & 0 & - & - & 1 & 0 & 0 \\
\hline Nematoda $(<200 \mu \mathrm{m})$ & $1-4$ & 478 & 8 & 0.01 & 1 & 50 & 67 & 34 & 2 & 256 & 3 \\
\hline Nematoda total & $0-4$ & 5899 & 97 & & 76 & & & & & 3512 & 41 \\
\hline \multicolumn{12}{|l|}{ Ostracoda } \\
\hline Candona neglecta & $0-1$ & 16 & 0.3 & 1.7 & 4 & 147 & 460 & 25 & 6 & 3947 & 46 \\
\hline Heterocyprideis sorbyana & $0-1$ & 6 & 0.1 & 2.6 & 3 & 2 & 8 & 0.0 & 6 & 33 & 0.4 \\
\hline Paracyprideis fennica & $0-1$ & 20 & 0.3 & 2.8 & 9 & 6 & 18 & 1 & 6 & 336 & 4 \\
\hline Leptocythere lacertosa & $0-1$ & 0.2 & 0.0 & 0.6 & 0 & 43 & - & - & 1 & 5 & 0.1 \\
\hline Ostracoda total & & 42 & 1 & & 16 & & & & & 4321 & 50 \\
\hline \multicolumn{12}{|l|}{ Harpacticoida } \\
\hline$p_{\text {seudobradya } \mathrm{sp}}$ & $0-1$ & 64 & 1 & 0.3 & 3 & 21 & 36 & 11 & 6 & 412 & 5 \\
\hline Microarthridion littorale & $0-1$ & 6 & 0.1 & 1.4 & 1 & 4 & 4 & 4 & 1 & 31 & 0.4 \\
\hline Harpacticoida total & & 70 & 1.2 & & 4.5 & & & & & 443 & 5 \\
\hline \multicolumn{12}{|l|}{ Other groups } \\
\hline Kinorhyncha & $0-1$ & 37 & 1 & 0.3 & 2 & 1 & 3 & 0.4 & 6 & 15 & 0.2 \\
\hline Macoma balthica (spat) & $0-1$ & 3 & 0.0 & 1.2 & 1 & 67 & 122 & 37 & 5 & 247 & 3 \\
\hline Oligochaeta & $0-1$ & 0.5 & 0.0 & 10.4 & 1 & 0.3 & 0.3 & 0.3 & 1 & 1 & 0.0 \\
\hline Priapulida & $0-1$ & 0.5 & 0.0 & $\cdot$ & - & - & - & - & 1 & 1 & 0.0 \\
\hline Turbellaria & $0-1$ & 9 & 0.1 & $\cdot$ & - & - & - & - & 3 & 52 & 1 \\
\hline Other groups total & & 50 & 0.8 & & - & & & & & 316 & 4 \\
\hline
\end{tabular}




\section{RESULTS}

\section{Composition}

Total number of meiobenthic animals in the cores was on average 1212 ind. $10 \mathrm{~cm}^{-2}$. Apart from the nematodes, all groups were primarily confined to the 0 to $1 \mathrm{~cm}$ sediment layer. Nematodes were the dominant major taxon comprising on average $97 \%$ of the total abundance (Table 1). Most of these occurred in the 0 to $1 \mathrm{~cm}$ layer $(83 \%)$ where small nematodes, Leptolaimus papilliger, L. elegans, Microlaimus globiceps and Calomicrolaimus honestus, dominated. Of the larger nematodes Sabatieria pulchra occurred in similar numbers in both sediment layers, while other species were more abundant in the upper layer (Table 1). Harpacticoid copepods and ostracods were found in low numbers or on average 14 and 8 ind $10 \mathrm{~cm}^{-2}$, respectively. Nematodes, ostracods and harpacticoids comprised 76 , 16 and $4 \%$ of the total biomass, respectively. The large nematode species contributed more than $60 \%$ of the total meiofauna biomass. In terms of biomass, $S$. pulchra was by far the most important meiofauna species, contributing over $40 \%$ of the total meiofauna biomass. Other groups were found in low numbers and contributed less than $5 \%$ to the total biomass

\section{${ }^{14} \mathrm{C}$ uptake}

We accounted for $80 \%$ of the total label added, of which $34 \%$ was released as ${ }^{14} \mathrm{CO}_{2}$ (half of this was released in the first $7 \mathrm{~d}$ ), $1 \%$ was found as dissolved organic carbon, $55 \%$ remained in the sediment $(52 \%$ from 0 to $1 \mathrm{~cm}, 3 \%$ from 1 to $4 \mathrm{~cm}$ ) and only $0.04 \%$ was stored in meiofauna tissue.

The uptake of labelled diatom carbon varied greatly among major meiobenthic taxa and among species belonging to the same class or phylum (Table 1). Both total uptake and uptake per unit biomass were by far the highest in the ostracod Candona neglecta, accounting for $46 \%$ of the total meiofauna uptake. The radioactivity was much lower in other ostracods, apart from a single individual of Leptocythere lacertosa in which the radioactivity was relatively high (Table 1). There was a highly significant difference among the non-nematode species (ANOVA, p $<0.001$, Fig. 2) in both total uptake and the specific organic carbon activity (SOCA: DPM $\mu \mathrm{gC}^{-1}$ ). The total uptake of ${ }^{14} \mathrm{C}$ was significantly different among all 3 common ostracod species, Candona neglecta taking up 10 and 100 times more than Paracyprideis fennica and Heterocyprideis sorbyana, respectively (Tukey test, $\mathrm{p}<0.01$ ). Although the bivalve Macoma balthica took up in total about 10 times less ${ }^{14} \mathrm{C}$ than $C$. neglecta, the specific activity was not significantly different among these species (Tukey test, $\mathrm{p}>0.05$ ). The harpacticoid Pseudobradya sp. showed a higher SOCA than did the 2 ostracod species Paracyprideis fennica and Heterocyprideis sorbyana, but lower than $M$. balthica and $C$. neglecta (Tukey test, $\mathrm{p}<0.05$, Fig. 2)

Nematodes accounted for over $40 \%$ of the total meiofaunal uptake of ${ }^{14} \mathrm{C}$ in the cores, of which $84 \%$ was taken up by the large nematode species (Table 1). There was a significant difference in total ${ }^{14} \mathrm{C}$ among the nematode species (ANOVA, $p<0.05$, Fig. 2). Paracanthonchus spp. took up on average more ${ }^{14} \mathrm{C}$ than other species though this was only significant in comparison with Axonolaimus spinosus (Tukey test, $\mathrm{p}<$ 0.01 , Fig. 3). The SOCA was variable among species. In 2 species, Chromadorita fennica, and Eleutherolaimus stenosoma, there was no measurable uptake of radioactivity (Table 1). A. spinosus and Paracanthonchus spp. from the upper layer reached about a 4 times higher SOCA (ANOVA, $p<0.001$, Tukey-test, Fig. 3) than did Sabatieria pulchra (in either 0 to 1 or 1 to $4 \mathrm{~cm}$ depth layer). S. pulchra showed similar SOCA in both layers, and total uptake was not significantly
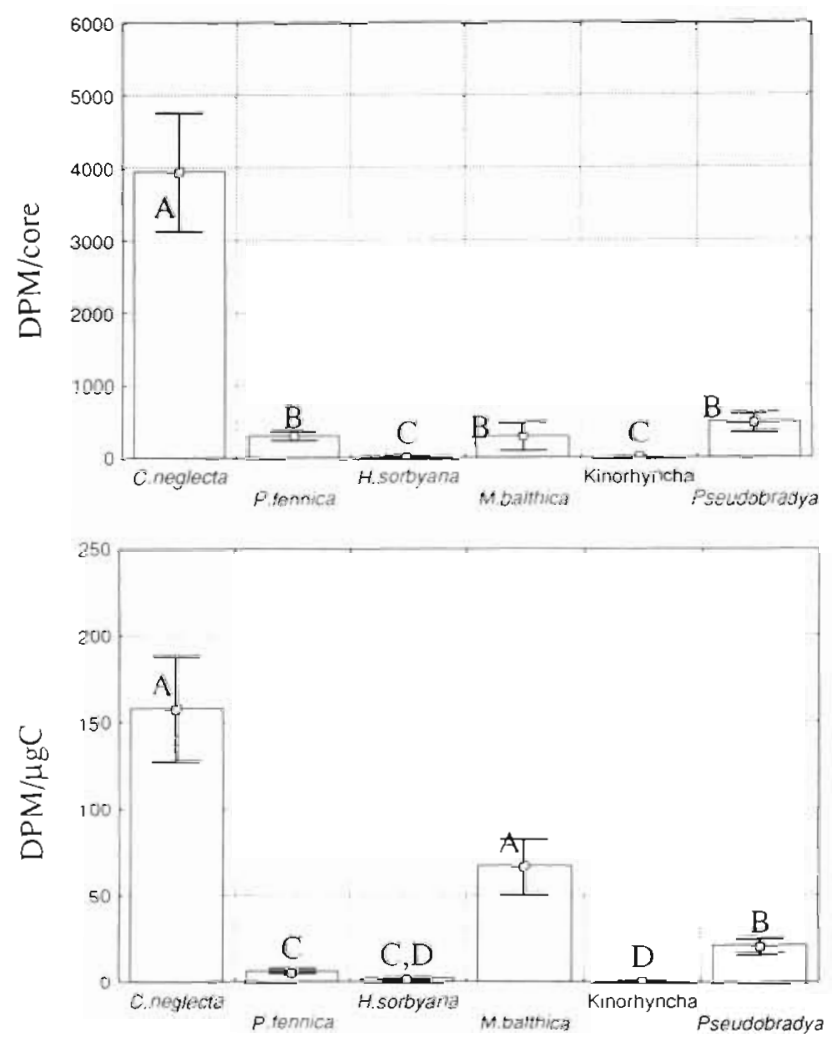

Fig. 2. Average $(\mathrm{n}=6$, for all but Macoma balthica $[\mathrm{n}=5]){ }^{14} \mathrm{C}$ uptake for the major non-nematode species/taxa in the 0 to $1 \mathrm{~cm}$ layer in the mesocosms. Common letter codes indicate no significant difference (Tukey test). (DPM: disintegrations per minute) 
different between the 2 layers (ANOVA, p > 0.05, Tukey-test, Fig 3). The few Parcanthonchus spp. found in the deeper layer had very similar SOCA as the surface population. Even though SOCA was about 2 times higher on average in the smaller nematodes in the deeper layer compared to the top layer this was not significant (Mann-Whitney $U$-test, $\mathrm{p}>0.05$ ).

\section{DISCUSSION}

This study clearly demonstrates that there are major interspecific differences in the assimilation of labelled material among the meiofauna species from the Baltic Sea. These differences occurred within all the major taxonomic groups in our experiment. The ostracod Candona neglecta accounted for almost half of the total meiofauna assimilation of the labelled material although it accounted for only $4 \%$ of the total meiofaunal biomass. This species is widely distributed throughout Europe, N Africa and Britain (Henderson 1990 ), and is abundant in the Baltic proper (Ólafsson \& Elmgren 1997). Little is known about its feeding habits,
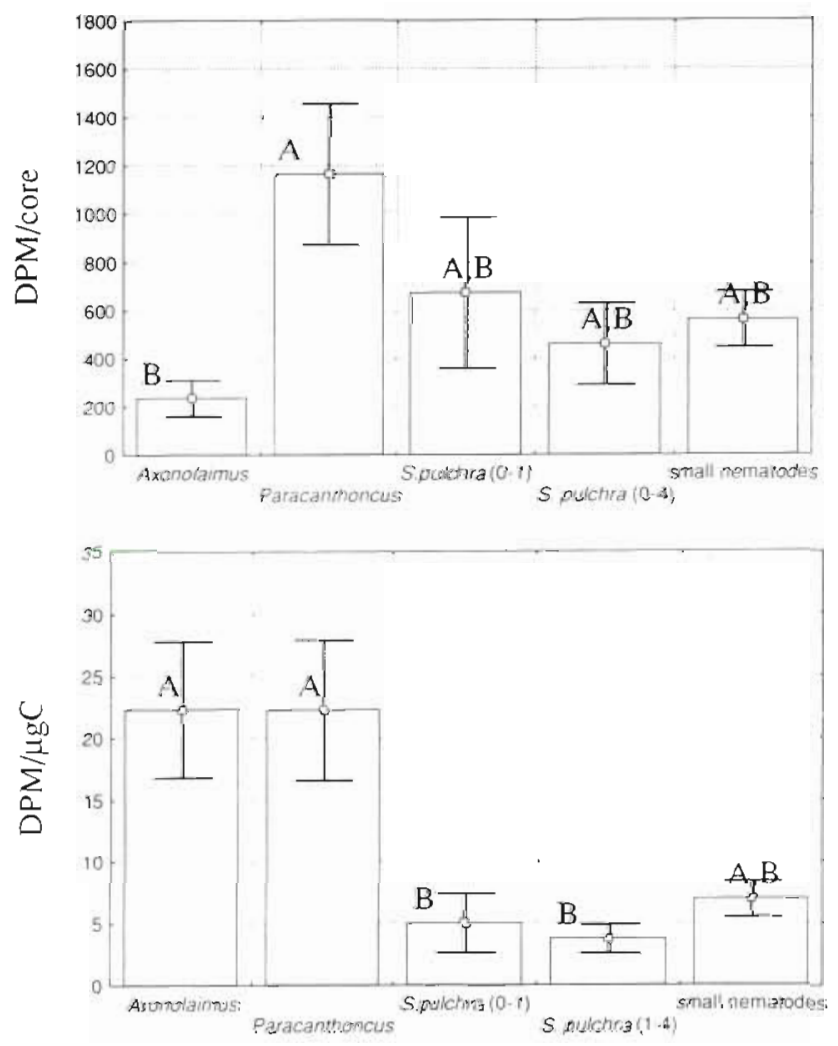

Fig. 3. Average ( $\mathrm{n}=6$, for all but Axonolaimus spinosus $[\mathrm{n}=5]\}{ }^{14} \mathrm{C}$ uptake for the major nematode species in the mesocosms. Only Sabatieria pulchra is presented from the 1 to $4 \mathrm{~cm}$ layer. Common letter codes indicate no significant difference (Tukey test) but ostracods in general eat a wide spectrum of both dead and living material, with diatoms representing a particularly common type of food (Athersuch et al. 1989, Henderson 1990). This study indicates that diatoms are a major food resource for $C$. neglecta after the settling of phytodetritus during spring.

The ostracods comprise the largest individuals of all the meiofauna taxa in the northern Baltic proper, and often contribute more than other taxa to the total biomass, they are more or less confined to the top $1 \mathrm{~cm}$ sediment layer (Ólafsson \& Elmgren 1991, 1997) and seem to be efficient feeders on detrital matter (laboratory observations). In 2 previous studies relatively high SOCA has been reported in ostracods (Rudnick 1989, Widbom \& Frithsen 1995). Therefore it was not surprising to note that these animals as a group were so efficient in assimilating the labelled material. However, the interspecific variation in the uptake of labelled material was not expected. There could be several reasons for this, one being little vertical separation. Such fine scale vertical stratification of meiofauna species has been found for both nematodes and harpacticoids, several species of which show clear segregation within the top $1 \mathrm{~cm}$ (Joint et al. 1982, Warwick \& Gee 1984, Fleeger et al. 1995). If Candona neglecta lives in the top millimeters of the sediment and the other 2 common ostracod species a few millimeters below, microhabitat location would obviously help to explain the interspecific difference we found. We have no data to support this speculation, however, and the study of other forms of resource partitioning may provide a better explanation for our results, e.g. food selection.

The few Macoma balthica spat in the microcosms also had high SOCA, comparable to Candona neglecta. In muddy substrates $M$. balthica is a deposit feeder, gathering food particles on the sediment surface (Hulscher 1973) and utilising detritus, microflora and microfauna as food (Newell 1965. Fenchel 1972. Tunnicliffe \& Risk 1977). Adults and juveniles seem to feed on similar sources, as intraspecific competition over food resources has been demonstrated in the laboratory (Bonsdorff et al. 1986, Ólafsson 1989). Our results therefore substantiate that these juveniles are feeding on surface material. The low SOCA of the kinorhynchs is in accordance with Rudnick (1989) and Widbom \& Frithsen (1995).

As a group the nematodes took up almost as much ${ }^{14} \mathrm{C}$ as the ostracods, but uptake was highly variable among species. Paracanthonchus spp. and Axonolaimus spinosus had much higher carbon-specific activity in their bodies than other nematodes. This was expected in the case of Paracanthonchus spp. as these nematodes showed a very clear increase in abundance after the settling of spring bloom material in a field study from the same site, i.e. Askö area fÓlafsson \& 
Elmgren 1997). Further, the structure of their buccal cavity (Fig. 4) places them in a group of nematodes that have been classified as epistrate feeders (Wieser 1953). These primarily feed on diatoms (Heip et al. 1985), either by cracking or piercing the cells with a large dorsal tooth, before sucking up the contents (e.g. Nehring 1992, Moens \& Vincx 1997). Another common relatively large epistrate feeder in the Asko area, Chromadorita fennica, was expected to utilise the diatoms as well, but clearly did not in our experiment. It is about half the size of Paracanthoncus spp. (Fig. 4) and perhaps too small to handle the Skeletonema costatum cells. We believe that this nematode selects some other phytal species which may be more easily eaten. For instance Jensen (1982) described how a species of the same genus, Chromadorita tenuis, brings one end of the pennate diatom Nitzschia sp. into the buccal cavity and then breaks it open, after which it sucks out the contents. We do not consider it likely that this species was scraping significant amounts of bacteria or other micro-organisms from the sediment grains, as some epistrate feeders do (e.g. Moens \& Vincx 1997), because no radioactivity was recorded at all in C. fennica. In contrast small nematodes, which are unable to eat diatoms, accumulated considerable radioactivity which must have originated from the uptake of radioactive micro-organisms or dissolved organic matter. The relatively high radioactivity in $A$. spinosus was not expected, as this species has no teeth in its buccal cavity (Fig. 4) and, therefore, is obviously not adapted to piercing or cracking diatoms. Moreover, though this species is quite common in the Baltic proper, it is usually found in low abundance and did not display significant variation among seasons ( $p>$ 0.05, Fig. 5) (data from Olafsson \& Elmgren 1997). It has a rather large buccal cavity and, hence, belongs to the non-selective deposit feeders (Wieser 1953) like other common nematodes from the Baltic proper, e.g. Sabatieria pulchra, Eleutherolaimus stenosoma and Desmolaimus zeelandicus (Fig. 4), all of which had much lower radioactivity in their bodies. Nonetheless diatoms are an important food resource for several representatives of deposit feeders (Moens \& Vincx 1997), which ingest diatoms entirely and digest them as they pass through the intestine (Nehring 1992). However $A$. spinosus might also have been feeding on microorganisms as well as dissolved organic matter. So among the so-called non-selective deposit feeders, there appears to be selection both for (in A. spinosus) and against (in E. stenosoma) certain food items in the Baltic Sea. Thus, classification of nematodes in feeding categories based on the morphology of the buccal cavity alone is not altogether reliable. Empirical data show that there is considerable variation within each feeding category (e.g. Jensen 1987, Moens \& Vincx 1997), and it seems to us that much more data are needed on the feeding habits of individual nematode species before an ecologically valid grouping of nematodes into feeding categories can be attempted.

We hypothesized that animals in the top $1 \mathrm{~cm}$ layer should display higher SOCA levels than the deeper living animals. This assumption was not borne out by the results, which contradicts Rudnick's (1989) hypothesis. He postulated that meiobenthic animals react in 2 ways to phytoplankton sedimentation, with surface feeders directly assimilating sedimented phytoplankton, while subsurface feeders experience a more stable food supply and rely only indirectly on sedimented phytoplankton. The nematode Sabatieria pulchra was found in similar numbers in both sediment layers, with
Fig. 4. The buccal cavity of the 7 most common large (retained on $200 \mu \mathrm{m}$ sieve) nematodes in the Kajak cores. (a) Paracanthonchus spp., (b) Chromadorita fennica, (c) Sabatieria pulchra, (d) Axonolaimus spinosus, (e) Eleutherolaimus stenosoma, (f) Desmolaimus zeelandicus, (g) Sphaerolaimus sp. The diatom Skeletonema costatum (h) is drawn to scale. Bar diagrams display the average DPM $\mathrm{ugC}^{-1}$ for each of the species in the 2 depth layers. *Not estimated

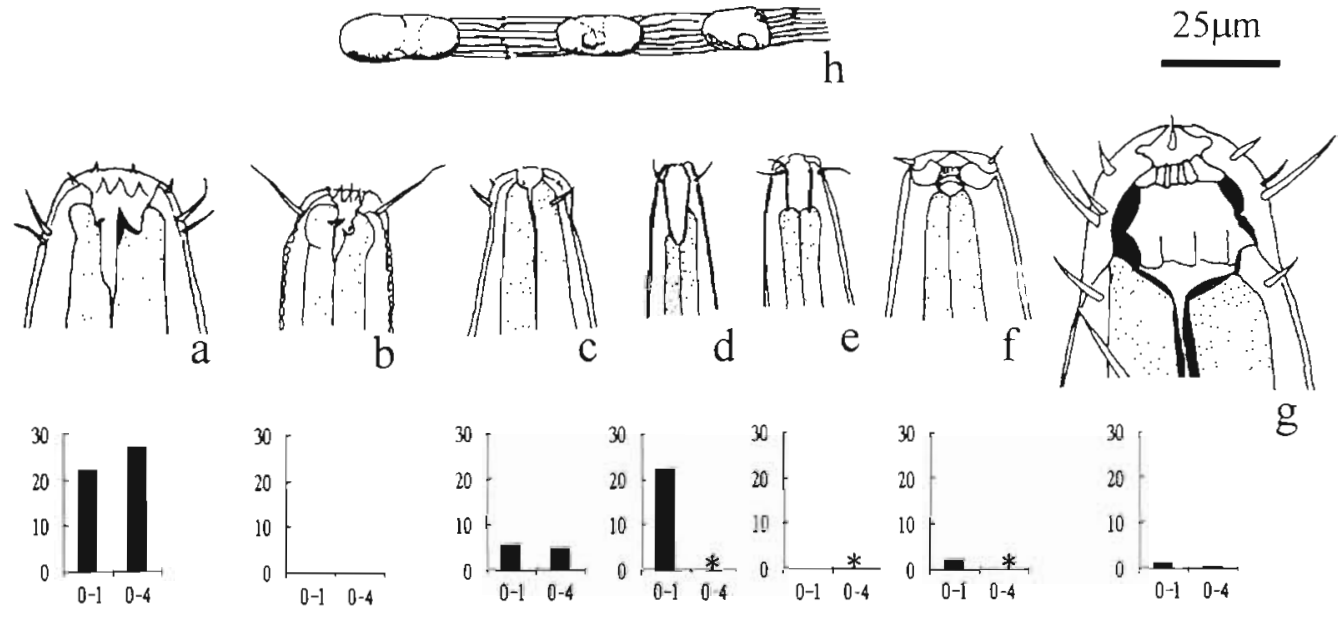

Epistrate feeders
Predator 


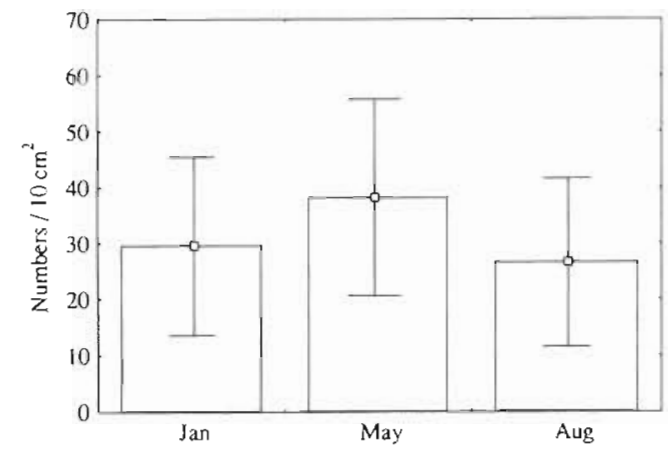

Fig. 5. Axonolaimus spinosus. Average numbers ( $\pm \mathrm{SE} ; \mathrm{n}=5$ ) of the nematode from 3 different seasons: January, May and August 1989 from the field station at Askö

no significant difference between layers in the SOCA levels determined in tissues. This species is typically found at depths near the redox potential discontinuity (RPD) layer and has shown tolerance to long periods of oxygen deficiency (Wieser \& Kanwisher 1961, Jensen 1981, 1983, Warwick \& Gee 1984, Olafsson 1992, Hendelberg \& Jensen 1993, Modig \& Ólafsson 1998). We have noted in the laboratory that freshly fixed individuals placed in brackish water regurgitate considerable amounts of ciliates (Ólafsson \& Dragas pers. obs.). We therefore suspect that the diatoms were partly broken down by micro-organisms and that the label entered these nematodes via the microbial community, possibly by feeding on ciliates. One can envisage a similar scenario for the small nematodes, which, due to their small buccal cavities, must feed upon micro-organisms or dissolved organic matter. Though we did not identify the small nematodes from the deeper layer it is likely that these were mainly Leptolaimus elegans and L. papilliger, as these tend to dominate deeper layers in the field (Ólafsson \& Elmgren 1991) and show high tolerance toward oxygen deficiency in the laboratory (Modig \& Olafsson 1998). Both are best described as microvores (sensu Moens \& Vincx 1997), with minute mouth openings ( 1 to $2 \mu \mathrm{m}$ ), unable to capture objects larger than bacteria (Romeyn \& Bouwman 1983). The radioactive material, $3 \%$ of the total measured in the sediment, may have reached the deeper layers by various different processes, such as meiofaunal burial (e.g. Webb \& Montagna 1993), migration of micro- and meiofaunal organisms or by passive transport of dissolved organic carbon.

The lack of a significant difference between surface and deeper living nematodes may also be explained by vertical migration in the sediment during the course of the experiment. It is plausible that some of the nematodes isolated from the deeper layers spent some time feeding in the surface layer. However, we have no data to substantiate such migration for the species in question.
A passive 'uptake' of label by the meiofauna is always possible via absorption and adsorption of the radioactive material. Also, uptake of dissolved organic matter by epibiotic bacteria associated with meiofauna can vary dramatically among species (Carman 1994. Carman \& Dobbs 1997). However we do not believe that this was important in the present experiment because of the following. (1) In experimental units, where meiofauna were killed with formalin prior to adding the radioactive material, the SOCA was similar among ostracod species and was a small fraction of the SOCA found in experimental units where meiofauna were not killed with formalin (Table 2). (2) In closely related species SOCA was often found to be very different. (3) The sediment in the 1 to $4 \mathrm{~cm}$ layers had about 17 times lower radioactivity than in the 0 to $1 \mathrm{~cm}$ layers, but the assimilated label and SOCA in nematodes was not higher in the upper layer.

Even though more than $50 \%$ of the added diatom carbon was still in the sediment and only $0.04 \%$ was stored in the tissues of meiobenthic animals after $1 \mathrm{mo}$, the sedimentation of Skeletonema costatum could be of major significance for the meiobenthic community. Clearly meiofauna processed much more than $0.04 \%$ of the labelled diatoms when taking into consideration meiofaunal respiration, multiple gut passage times and meiofaunal mortality over the 1 mo experiment. Further a considerable part of the label may be lost due to fixation in formaldehyde (Moens \& Vincx 1996). Even 3 mo after settling, a large proportion of the diatoms may still be present in the sediment (van de Bund et al. unpubl.), which is in agreement with many laboratory studies from other areas (e.g. Andersen \& Kristensen 1992, Fitzgerald \& Gardner 1993, Gullberg et al. 1997). This material may thus fuel the benthic communities at relatively constant rates over longer periods, especially the microvores. This appears to be the case for several dominant nematode species in the Askö area, where a slight increase in numbers after the spring bloom and then a gradual decrease during the rest of the year have been noted (Ólafsson \& Elmgren 1997).

Table 2. Average specific organic carbon activity for (SOCA) 3 common ostracod species in formalin-treated microcosms $(\mathrm{n}=2)$ and in microcosms not treated with formalin $(\mathrm{n}=5)$

\begin{tabular}{|c|c|c|}
\hline Species & $\begin{array}{l}\text { With formalin } \\
\text { DPM } \mu \mathrm{gC}^{-1}\end{array}$ & $\begin{array}{l}\text { Without formalin } \\
\text { DPM } \mu \mathrm{gC}^{-1}\end{array}$ \\
\hline Paracyprideis fennica & 2.24 & 28 \\
\hline Heterocyprideis sorbyana & 1.40 & 10 \\
\hline Candona neglecta & 3.75 & 643 \\
\hline
\end{tabular}


Acknowledgements. Many thanks to Nils Walberg for building the microcosms, the staff at the Asko Laboratory for field assistance and to Lars-A.ke Gisselsson for providing algae for culturing. Tom Moens and Kevin R. Carman gave valuable comments on earlier versions of the manuscript. This research was partly supported by a Marie Curie postdoctoral fellowship to W.v.d.B., and NFR grant to Ragnar Elmgren.

\section{LITERATURE CITED}

Alongi DM, Tietjen JH (1980) Population growth and trophic interactions among free-living marine nematodes. In: Tenore KR, Coull BC (eds) Marine benthic dynamics. University of South Carolina Press, Columbia, p 151-166

Andersen FO, Kristensen $E$ (1992) The importance of benthic macrofauna in decomposition of microalgae in a coastal marine sediment. Limnol Oceanogr 37:1392-1403

Athersuch J, Horne DC, Whittaker JE (1989) Marine and brackish water ostracods. In: Kermack DM, Barnes RSK (eds) Synopsis of the British fauna (New Series). Vol 43. EJ Brill, New York

Austen MC, Warwick RM (1995) Effects of manipulation of food supply on estuarine meiobenthos. Hydrobiologia 311. $175-184$

Blomqvist S, Larsson U (1994) Detrital bedrock elements as tracers of settling resuspended particulate matter in a coastal area of the Baltic Sea. Limnol Oceanogr 39: $880-896$

Bonsdorff E, Matilla J, Rönn C, Österman CS (1986) Multidimensional interactions in shallow soft-bottom ecosystems; testing the competitive exclusion principle. Ophelia 4: $37-44$

Carman KR (1990) Radioactive labeling of a natural assemblage of marine sedimentary bacteria and microalgae for trophic studies. Microb Ecol 19:279-290

Carman KR (1994) Stimulation of marine free-living and epibiotic bacterial activity by copepod excretions. FEMS Microbiol Ecol 14:255-262

Carman KR, Dobbs FC (1997) Epibiotic microorganisms on copepods and other aquatic crustaceans. Microsc Res Tech 37:116-135

Carman KR, Dobbs FC, Guckert JB (1989) Comparison of three techniques for administering radiolabeled substrates to sediments for trophic studies: uptake of label by harpacticoid copepods. Mar Biol 119-125

Daro $\mathrm{MH}$ (1978) A simplified ${ }^{14} \mathrm{C}$ method for grazing measurements on natural planktonic populations. Helgol Wiss Meeresunters 31:241-248

Decho AW (1986) Water-cover influences on diatom ingestion rates by meiobenthic copepods. Mar Ecol Prog Ser 33 $139-146$

Decho AW, Fleeger JW (1988) Ontogenetic feeding shifts in the meiobenthic harpacticoid copepod Nitocra lacustris Mar Biol 97:191-197

Fenchel $T$ (1972) Aspects of decomposer food chains in marine benthos. Verh Dt Zool Ges 65:14-22

Fitzgerald SA, Gardner WS (1993) An algal carbon budget for pelagic-benthic coupling in Lake Michigan. Limnol Oceanogr 38:547-560

Fleeger JW, Shirley TC (1990) Meiofaunal responses to sedimentation from an Alaskan spring bloom. II. Harpacticoid population dynamics. Mar Ecol Prog Ser 59:239-247

Fleeger JW, Shirley TC, Ziemann DA (1989) Meiofaunal responses to sedimentation from an Alaskan spring bloom. I. Major taxa. Mar Ecol Prog Ser 57:137-145

Fleeger JW, Shirley TC, MCCall JN (1995) Fine-scale vertical profiles of meiofauna in muddy subtidal sediments. Can J Zool 73:1453-1460

Goedkoop W, Johnson RK (1996) Pelagic-benthic coupling: profundal benthic community response to spring diatom deposition in mesotrophic Lake Erken. Limnol Oceanogr $41: 636-647$

Gooday AJ, Pfannkuche O, Lambshead PJD (1996) An apparent lack of response by metazoan meiofauna to phyto-detritus deposition in the bathyal north-eastern Atlantic. J Mar Biol Assoc UK 76:297-310

Graf G (1992) Benthic-pelagic coupling: a benthic view. Oceanogr Mar Biol Annu Rev 30:149-190

Guillard RL (1975) Culture of phytoplankton for feeding marine invertebrates. In: Smith WL, Chandley MH (eds) Culture of marine invertebrate animals. Plenum Press, New York

Gullberg KR, Goedkoop W, Johnson RK (1997) The fate of diatom carbon within a freshwater benthic community - a microcosm study. Limnol Oceanogr 42:452-460

Heip C, Vincx M, Vranken G (1985) The ecology of marine nematodes. Oceanogr Mar Biol Annu Rev 23:399-489

Heip CH, Goosen NK, Herman PMJ, Kromkamp J, Middelburg JJ, Soetaert K (1995) Production and consumption of biological particles in temperate tidal estuaries. Oceanogr Mar Biol Annu Rev 33:1-149

Heiskanen AS, Kononen K (1994) Sedimentation of vernal and late summer phytoplankton communities in the coastal Baltic Sea. Arch Hydrobiol 131:175-198

Hendelberg $M$, Jensen P (1993) Vertical distribution of the nematode fauna in a coastal sediment influenced by seasonal hypoxia in the bottom water. Ophelia 38:1-11

Henderson PA (1990) Freshwater ostracods. In: Kermack DM, Barnes RSK (eds) Synopsis of the British fauna (New Series). Vol 42. Universal Book Services, Oegstgeest

Hicks GRF, Coull BC (1983) The ecology of marine meiobenthic harpacticoid copepods. Oceanogr Mar Biol Annu Rev 21:67-175

Hulscher JB (1973) Burying-depth and trematode infection in Macoma balthica. Neth J Sea Res 6:141-156

Jensen P (1981) Species, distribution and a microhabitat theory for marine mud dwelling Comesomatidae (Nematoda) in European waters. Cah Biol Mar 22:231-241

Jensen P (1982) Diatom-feeding behaviour of the free-living marine nematode Chromadorita tenuis. Nematologica 28: $71-76$

Jensen $\mathrm{P}$ (1983) Meiofaunal abundance and vertical zonation in a sublittoral soft bottom, with a test of the Haps corer. Mar Biol 74:319-327

Jensen P (1987) Feeding ecology of free-living aquatic nematodes. Mar Ecol Prog Ser 35:187-196

Joint IR, Gee MJ, Warwick RM (1982) Determination of finescale vertical distribution of microbes and meiofauna in an intertidal sediment. Mar Biol 72:157-164

Kester DR, Duedall IW, Connors DN, Pykovocz RM (1967) Preparation of artificial seawater. Limnol Oceanogr 12: $176-179$

Kononen K, Nommann S, Hansen G, Hansen R, Breuel G, Gupalo E (1992) Spatial heterogeneity and dynamics of vernal phytoplankton species in the Baltic Sea in April-May 1986. J Plankton Res 14:107-125

Kuparinen J, Leppäanen JM, Sarvala J, Sundberg A, Virtanen $A$ (1984) Production and utilization of organic matter in a Baltic ecosystem off Tvärminne, southwest coast of Finland. Rapp PV Réun Cons Int Explor Mer 183:180-192

Lignell $\mathrm{R}$, Heiskanen AS, Kuosa $\mathrm{H}$, Gundersen $\mathrm{K}$, KuuppoLeinikki P, Pajuniemi R, Uitto A (1993) Fate of a phytoplankton spring bloom: sedimentation and carbon flow in 
the planktonic food web in the northern Baltic. Mar Ecol Prog Ser 94:239-252

Modig $\mathrm{H}_{1}$ Olafsson E (1998) Responses of Baltic benthic invertebrates to hypoxic events. J Exp Mar Biol Ecol 229: $133-148$

Moens T, Vierstraete A, Vincx M (1996) Life strategies in two bacterivoruous marine nematodes: preliminary results. PSZN I: Mar Ecol 17:509-518

Moens $T$, Vincx $M$ (1996) Do meiofauna consume primary production? About many questions and how to answer them. In: Baeyens J, Dehairs F, Goeyns L (eds) Integrated marine system analysis. Minutes of the first network meeting (Brugge, Belgium, 29.02-2.03.96) of the European Network for Intergrated Marine System Analysis, Belgian National Fund for Scientific Research (NFWO). VUB University Press, Brussels, p 188-202

Moens T, Vincx M (1997) Observations on the feeding ecology of estuarine nematodes. J Mar Biol Assoc UK 77: 211-227

Montagna P (1983) Live controls for radioisotope tracer food chain experiments using meiofauna. Mar Ecol Prog Ser $12: 43-46$

Montagna P (1984) In situ measurement of meiobenthic grazing rates on sediment bacteria and edaphic diatoms. Mar Ecol Prog Ser 18:119-130

Montagna P, Blanchard GF, Dinet A (1995) Effects of production and biomass of intertidal microphytobenthos on meiofaunal grazing rates. J Exp Mar Biol Ecol 185 : $149-165$

Nehring S (1992) Die Vegetarier unter den freilebenden Nematoden. 2. Die Depositfresser. Mikrokosmos 81: $260-266$

Newell RC (1965) The role of detritus in the nutrition of two marine deposit feeders, the prosobranch Hydrobia ulvae and the bivalve Macoma balthica. Proc Zool Soc Lond 144: $25-45$

Ólafsson EB (1989) Contrasting influences of suspensionfeeding and deposit-feeding populations of Macoma balthica on infaunal recruitment. Mar Ecol Prog Ser 55 . $171-179$

Olafsson E (1992) Small-scale distribution of marine meiobenthos: the effects of decaying macrofauna. Oecologia 90 : $37-42$

Olafsson E, Elmgren R (1991) Effects of biological disturbance by benthic amphipods Monoporeia affinis on meiobenthic community structure: a laboratory approach. Mar Ecol Prog Ser 74:99-107

Editorial responsibility: Otto Kinne (Editor).

Oldendorf/Luhe, Germany
Ólafsson E, Elmgren R (1997) Seasonal dynamics of sublittoral meiobenthos in relation to phytoplankton sedimentation in the Baltic Sea. Estuar Coast Shelf Sci 45:149-164

Pace MC, Carman KR (1996) Interspecific differences among meiobenthic copepods in the use of microalgal food resources. Mar Ecol Prog Ser 143:77-86

Radziejewska T, Fleeger JW, Rabalais NN, Carman KR (1996) Meiofauna and sediment chloroplastic pigments on the continental shelf off Louisiana, U.S.A. Cont Shelf Res 16:1699-1723

Romeyn K, Bouwman LA (1983) Food selection and consumption by estuarine nematodes. Hydrobiol Bull 17:103-109

Rudnick DT (1989) Time lags between the deposition and meiobenthic assimilation of phytodetritus. Mar Ecol Prog Ser 50:231-240

Schiemer F (1984) Comparative aspects of food dependence and energetics of freeliving nematodes. Oikos 41:32-42

Smetacek $V$, von Bodungen $B$, Knoppers $B$, Peinert $R$, Pollehne F, Stegmann P, Zeitschel B (1984) Seasonal stages characterizing the annual cycle of an inshore pelagic system. Rapp PV Réun Cons Int Explor Mer 183: $126-135$

Tunnicliffe V, Risk MJ (1977) Relationships between the bivalve Macoma balthica and bacteria in intertidal sediments: Minas Basin, Bay of Fundy. J Mar Res 35:499-507

Van den Berghe W, Bergmans M (1981) Differential food preferences in three co-occurring species of Tisbe (Copepoda, Harpacticoida). Mar Ecol Prog Ser 4:213-219

Warwick RM, Gee JM (1984) Community structure of estuarine meiobenthos. Mar Ecol Prog Ser 18:97-111

Webb DG (1996) Response of macro- and meiobenthos from a carbon-poor sand to phytodetrital sedimentation. J Exp Mar Biol Ecol 203:259-271

Webb DG, Montagna PB (1993) Initial burial and subsequent degradation of sedimented phytoplankton: relative impact of macro- and meiobenthos. J Exp Mar Biol Ecol 166: $151-163$

Widbom B, Frithsen JB (1995) Structuring factors in a marine soft bottom community during eutrophication - an experiment with radio-labelled phytodetritus. Oecologia 101: $156-158$

Wieser W (1953) Die Beziehung zwischen Mundhöhlengestalt, Ernährungsweise und Vorkommen bei freilebenden marinen Nematoden. Ark Zool 4:439-484

Wieser W, Kanwisher J (1961.) Ecological and physiological studies on marine nematodes from a salt marsh near Woods Hole, Massachusetts. Limnol Oceanogr 6:262-270

Submitted: July 10, 1998; Accepted: October 22, 1998

Proofs received from author(s): February 5, 1999 